\title{
Taxonomy of the Genus Microcyclus Drskov 1928: Reintroduction and Emendation of the Genus Spirosoma Migula 1894 and Proposal of a New Genus, Flectobacillus
}

\author{
JOHN M. LARKIN, PATRICIA M. WILLIAMS, AND ROBERT TAYLOR \\ Department of Microbiology, Louisiana State University, Baton Rouge, Louisiana 70803
}

\begin{abstract}
The type strains of the three currently recognized species of the genus Microcyclus Orskov 1928 ( $M$. aquaticus Orskov, strain ATCC 25396; M. major Gromov, strain BKM 859; and $M$. flavus Raj, strain ATCC 23276), together with strains apparently belonging to each species, were examined to determine their taxonomic relationships. There were many differences between the type strains in their morphological and physiological characteristics as well as in the guanine-plus-cytosine $(G+C)$ contents of their deoxyribonucleic acids (DNAs). Therefore, we propose to split the genus Microcyclus into three genera, each containing a single species. $M$. aquaticus, the type species of Microcyclus, remains as the only species in the genus. It is characterized by the formation of cellular rings which are produced when the ends of the curved cells overlap. It is nonpigmented and is respiratory in its metabolism; the $\mathrm{G}+\mathrm{C}$ content of its DNA ranges from 66.3 to $68.4 \mathrm{~mol} \%$. M. flavus ATCC 22376 and three similar strains were found to possess characters in agreement with those given in the original description of Spirosoma linguale, and they were placed in that species. The name $M$. flavus Raj 1970 thus becomes a later subjective synonym of Spirosoma linguale (Eisenberg 1891) Migula 1894. This species is characterized by the formation of wavy and coiled filaments, yellow pigmentation on MicrocyclusSpirosoma (MS) agar, and respiratory metabolism. The G+C content of its DNA ranges from 51.0 to $52.9 \mathrm{~mol} \%$. Strain DSM 74 is designated as the neotype strain of S. linguale. M. Major BKM 859 and one similar strain were placed in a new genus, Flectobacillus. F. major (Gromov) comb. nov., the type species, is composed of rods which are straight to curved, the degree of curvature varying among individual cells within a culture. The cells may form long, sinuous filaments and rings. Colonies on MS agar are pale pink to rose-colored. Metabolism is respiratory, and the $\mathrm{G}+\mathrm{C}$ content of its DNA ranges from 39.5 to 40.3 mol\%. The type strain of $F$. major is strain BKM 859 .
\end{abstract}

In the eighth edition of Bergey's Manual (19), the genus Microcyclus Đrskov 1928 is a heterogenous collection of three species: $M$. aquaticus Orskov (the type species), $M$. flavus Raj, and $M$. major Gromov. All three species were described and named on the basis of single strains, and these strains (see below) are, therefore, according to Rule $18 \mathrm{C}$ of the Bacteriological Code (12), type strains by monotypy. The lack of additional strains of these species has been a hindrance in conducting a comprehensive study of this genus. However, Claus (4) determined that two organisms isolated in Europe and designated as Spirosoma sp. were similar to $M$. flavus. On the basis of the base compositions of the DNAs, Claus et al. (5) suggested that the three Microcyclus species represented three different taxa and that $M$. flavus should be placed in the little-used genus Spirosoma Migula 1894. Recently, we isolated from bodies of water near Baton Rouge, La., an organism which resembled $M$. flavus, another which resembled $M$. major, and several strains which resembled $M$. aquaticus. With these additional strains available, a comprehensive study of the taxonomic relationships of these three species was made.

\section{MATERIALS AND METHODS}

Bacterial strains. Cultures of the following type strains were obtained from the Deutsche Sammlung von Mikroorganismen (DSM) through the kindness of D. Claus of Göttingen, Germany: the Orskov strain of $M$. aquaticus (DSM $101=$ ATCC 25396) and the Gromov strain of $M$. major (DSM $109=\mathrm{BKM}$ 859). Spirosoma sp. strains 1 and 2 were also obtained from D. Claus with the accession numbers DSM 74 and DSM 75, respectively. A culture of the type strain of $M$. flavus was obtained from the American Type Culture Collection (ATCC), Rockville, Md., under the number 23276. Strains 3 and 5 
and strain $1 \mathrm{C}$ of $M$. aquaticus were isolated in this lab. Cultures of the above-mentioned strains were maintained on slants of Microcyclus-Spirosoma (MS) agar of the following composition: $0.1 \%$ each of glucose, peptone, and yeast extract plus $1.5 \%$ agar. Transfers were made at intervals of about 2 weeks with incubation at $25^{\circ} \mathrm{C}$.

Utilization of carbohydrates. The production of acid by aerobic or anaerobic means from carbohydrates was determined by the method of Hugh and Leifson (11). Incubation was continued for 8 weeks for cultures which gave negative results.

Utilization of single carbon sources. The basal medium of Gordon and Mihm (8), to which was added $0.2 \%$ of the substrate or the sodium salt of the substrate, was used. If growth occurred through four successive subcultures, the results were considered positive even in the absence of a color change in the bromothymol blue indicator.

Hydrolysis of macromolecules. Gelatin and starch hydrolyses were detected by zones of hydrolysis surrounding colonies on plate cultures (10). Gelatin hydrolysis was also determined in stab tubes of nutrient gelatin. Casein hydrolysis was detected by zones of clearing around colonies on nutrient agar containing $10 \%$ (vol/vol) of skim milk. Cellulose and chitin hydrolyses were determined by inoculating the surfaces of double-layered plates and looking for zones of clearing. The bottom layer consisted of MS medium (but with $1 \%$ agar) with $0.2 \%$ of powdered cellulose or chitin in place of the glucose; the thin upper layer contained 10\% (wt/vol) of the substrate and $1 \%$ agar in distilled water. Cellulose decomposition was also examined by inoculating filter paper layered over the bottom medium. Esculin and tributyrin hydrolyses were detected by the methods described by Holding and Collee (10).

Production of specific enzymes or end products. The methyl red and Voges-Proskauer (VP) tests, the tests for the production of indole and $\mathrm{H}_{2} \mathrm{~S}$, and the tests for $\beta$-galactosidase (ONPG), oxidase, catalase, phosphatase, urease, lecithinase, phenylalanine deaminase, lysine decarboxylase, ornithine decarboxylase, and the reduction of nitrate were performed by the methods described by. Holding and Collee (10). In addition, tests for urease, lysine and ornithine decarboxylases, lysine deaminase, ONPG, oxidase, nitrate reduction, indole, $\mathrm{H}_{2} \mathrm{~S}$ production, VP, malonate utilization, and esculin hydrolysis were performed by the PathoTec Rapid I-D System (Warner-Lambert Co., Morris Plains, N. J.). Results were the same by either method unless specified otherwise.

Susceptibility to antibiotics. Except for actinomycin D, susceptibility to antibiotics and sulfa drugs was determined by placing antibiotic-impregnated disks on the surface of MS agar inoculated with the organisms. Susceptibility to actinomycin D was detected by the method of Dworkin (6).

Ability to grow on various media. The abilities of the organisms to grow on various media were investigated by making a single streak of the organism from a fresh slant over the surface of the medium and incubating at $25^{\circ} \mathrm{C}$ for a minimum of 3 weeks. The media tested were chocolate agar, blood agar, eosin methylene blue agar, phenol red mannitol salt agar, phenyl ethyl alcohol agar, nutrient agar, nutrient agar $+5 \%$ sucrose (NAS), Trypticase soy agar (TSA), TSA + 3\% sucrose, TSA + 3\% glucose (TSAG), peptonized milk agar, MS agar, yeast extract acetate tryptone agar, McConkey agar, bismuth sulfide agar, and Salmonella-Shigella agar.

Additional characters. Deoxyribonucleic acid (DNA) was purified by the method of Marmur (14), and the moles percent guanine plus cytosine $(G+C)$ was calculated from the melting-point profile obtained with a Gilford model 2400 spectrophotometer equipped with a temperature-controlled cuvette compartment (13). Measurements of cell size were obtained with a Filar micrometer. A Gillet and Seibert microscope equipped with a Nikon model AFM camera was used for photomicrography.

\section{RESULTS}

The strains fell into three distinct groups, which are differentiated in Tables 1 to 7 . In Table 1 , it can be seen that $M$. flavus ATCC 23276 , the Spirosoma strains, and strain 5 produce curved rods which tend to form long, undulating filaments and coiled spirals and which produce yellow colonies. The $\mathrm{G}+\mathrm{C}$ contents of the DNAs of these four strains range from 51.0 to $52.9 \mathrm{~mol} \%$. M. major strain Gromov and strain 3 produce curved rods which form long, undulating filaments but which form coiled spirals only infrequently; both strains produce pink colonies. The $\mathrm{G}+\mathrm{C}$ contents of the DNAs of these two strains range from 39.5 to 40.3 mol\%. The cells of $M$. aquaticus strains Drskov and $1 \mathrm{C}$ are smaller than those of the other strains and never form filaments or coils. The colonies of these strains are white. The $\mathrm{G}+\mathrm{C}$ value of both strains is $67.3 \mathrm{~mol} \%$, which is much higher than the values of the strains of the other two groups. The clear differences in cellular morphology of the three groups are shown in Fig. 1.

Table 2 shows that all of the organisms were active in producing acid oxidatively from pentoses and hexoses. The $M$. aquaticus strains were less active than the strains of the other groups on glucosides, disaccharides, trisaccharides, and polysaccharides. After prolonged incubation, the tubes of carbohydrate which were covered with a mineral oil seal, and were presumably anaerobic, would often show acid production, contrary to previous reports $(1,19)$. Therefore the ability of each organism to grow anaerobically under a pyrogallol-KOH seal was tested, and all results were negative. It was concluded that the strains cannot grow anaerobically and that the delayed acid production in the mineral-oil-covered tubes was due to slow diffusion of oxygen. Acid production in the aerobic tubes always began at or near the sur- 


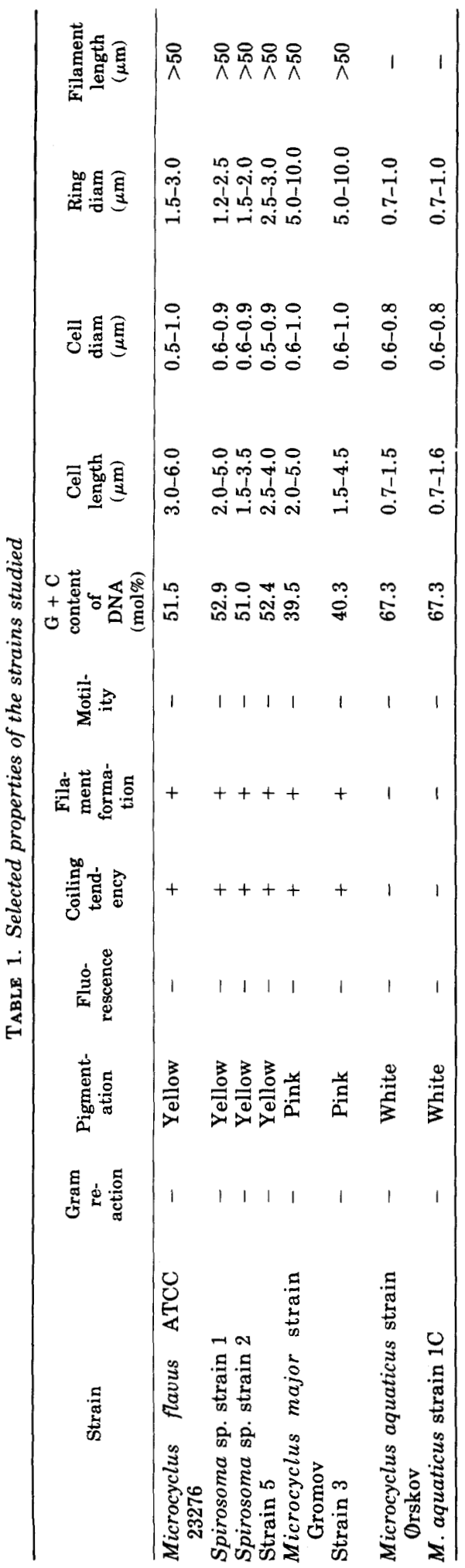

face, indicating that a respiratory acid-producing mechanism was also functional.

In contrast to these results, the $M$. aquaticus strains were the only organisms to produce acid from alcohols.

The three groups were quite different in their abilities to produce specific enzymes or end products (Table 3). Strains of the " $M$. major" group and of the " $M$. aquaticus" group produced urease, whereas strains of the " $M$. flavus" group did not. Only the $M$. aquaticus strains produced ornithine decarboxylase or reduced nitrates to nitrites. Strains of the $M$. major group produced phosphatase, the $M$. aquaticus strains did not, and two yellow strains produced only slightly positive reactions.

The $M$. aquaticus strains were the only ones unable to hydrolyze gelatin, starch, casein, and esculin, and the three groups were quite distinctive in their reactions in litmus milk (see Table 4).

Differences in the abilities of the organisms to utilize single carbon sources may be seen in Table 5. The $M$. aquaticus strains were the most versatile, for not only did they utilize succinate and malate, but also they were the only organisms to utilize acetate, citrate, and formate. Strains of the $M$. major group were the only ones to utilize glycerol phosphate and tartrate; in addition, the members of this group utilized succinate and malonate.

In general, the $M$. aquaticus strains were able to grow on a wider variety of media than were the organisms in the other two groups (Table 6), and high concentrations of carbohydrates ( 3 to $5 \%$ ), as in NAS and TSAG media, inhibited members of one or both of the other two groups. In addition, rich media such as chocolate and blood agars and TSA generally were not suitable for the strains of $M$. flavus and $M$. major groups but supported good growth of the $M$. aquaticus strains.

Only the $M$. aquaticus strains were resistant to penicillin, gentamycin, actinomycin D, sulfathiazole, and sulfamethoxyzole/trimethopterin (Table 7).

\section{DISCUSSION}

In 1894, Migula (15) established the genus Spirosoma to contain the organism previously isolated and named Vibrio lingualis by Eisenberg (7). Migula described it as follows: "Cells are usually fairly wide, curved in the shape of a screw, nonmotile, without flagella, rigid, nonflexible, single, free, or in gelatinous clumps" (translated from the German).

In 1887 and 1888, Weibel $(20,21)$ isolated several curved organisms, which he described 
TABLE 2. Oxidative production of acid from carbohydrates and alcohols by the strains studied

\begin{tabular}{|c|c|c|c|c|c|c|c|c|}
\hline \multirow[b]{2}{*}{ Substrate } & \multicolumn{8}{|c|}{ Acid production ${ }^{a}$} \\
\hline & $\begin{array}{c}\text { Microcy- } \\
\text { clus fla- } \\
\text { vus } \\
\text { ATCC } \\
23276\end{array}$ & $\begin{array}{c}\text { Spiro- } \\
\text { soma sp. } \\
\text { strain } 1\end{array}$ & $\begin{array}{c}\text { Spiro- } \\
\text { soma sp. } \\
\text { strain } 2\end{array}$ & $\begin{array}{l}\text { Strain } \\
5\end{array}$ & $\begin{array}{l}\text { Microcy- } \\
\text { clus ma- } \\
\text { jor strain } \\
\text { Gromov }\end{array}$ & $\begin{array}{l}\text { Strain } \\
3\end{array}$ & $\begin{array}{l}\text { Microcy- } \\
\text { clus } \\
\text { aquati- } \\
\text { cus } \\
\text { strain } \\
\text { Orskov }\end{array}$ & $\begin{array}{c}\text { Microcy- } \\
\text { clus } \\
\text { aquati- } \\
\text { cus } \\
\text { strain 1C }\end{array}$ \\
\hline \multicolumn{9}{|l|}{ Pentoses } \\
\hline Arabinose & $\mathrm{A}_{3}$ & A & $\mathrm{A}_{3}$ & $\mathbf{A}_{3}$ & A & A & A & A \\
\hline Ribose & $\mathrm{A}$ & A & $A_{3}$ & $\mathrm{~A}$ & - & - & A & $\mathrm{A}$ \\
\hline Xylose & $\mathrm{A}$ & A & $\mathrm{A}$ & $\mathrm{A}$ & A & A & A & $\mathrm{A}$ \\
\hline \multicolumn{9}{|l|}{ Methyl pentose } \\
\hline Rhamnose & A & A & $\mathbf{A}_{3}$ & A & A & sl A & $\mathrm{A}_{3}$ & $\mathrm{~A}_{3}$ \\
\hline \multicolumn{9}{|l|}{ Hexoses } \\
\hline Fructose & A & A & $\mathbf{A}_{3}$ & A & A & A & A & A \\
\hline Galactose & $\mathrm{A}$ & $\mathrm{A}$ & $\mathrm{A}$ & $\mathrm{A}$ & $\mathrm{A}$ & $\mathrm{A}$ & A & A \\
\hline Glucose & A & A & A & A & A & A & A & A \\
\hline Mannose & A & A & A & A & A & A & $\mathrm{A}_{3}$ & $\mathrm{~A}_{3}$ \\
\hline Sorbose & - & - & - & - & - & - & - & - \\
\hline \multicolumn{9}{|l|}{ Glucosides } \\
\hline $\begin{array}{c}\alpha \text {-Methyl-D } \\
\text { glucoside }\end{array}$ & A & $\mathrm{A}$ & A & A & A & A & - & - \\
\hline Salicin & A & A & $\mathrm{A}$ & A & A & A & - & - \\
\hline \multicolumn{9}{|l|}{ Disaccharides } \\
\hline Cellobiose & A & A & A & $\mathrm{A}$ & A & A & - & - \\
\hline Lactose & A & A & A & $\mathrm{A}$ & A & $\mathrm{A}$ & - & - \\
\hline Maltose & $\mathrm{A}$ & A & A & A & A & A & - & - \\
\hline Melibiose & A & $\mathrm{A}$ & $\mathrm{A}$ & $\mathrm{A}$ & sl A & A & - & - \\
\hline Sucrose & A & A & A & $\mathrm{A}$ & A & A & - & - \\
\hline Trehalose & A & A & A & A & $\mathrm{A}$ & A & - & - \\
\hline \multicolumn{9}{|l|}{ Trisaccharide } \\
\hline Raffinose & $\mathrm{A}$ & A & A & A & A & sl A & - & - \\
\hline \multicolumn{9}{|c|}{ Polysaccharides } \\
\hline Dextrin & A & A & $\mathrm{A}_{3}$ & A & A & $\mathrm{A}$ & - & - \\
\hline Inulin & $\mathrm{A}$ & A & $A$ & A & A & - & - & - \\
\hline \multicolumn{9}{|l|}{ Alcohols } \\
\hline Glycerol & - & - & - & - & - & - & $\mathrm{A}$ & $\mathrm{A}$ \\
\hline Erythritol & - & - & - & - & - & - & - & - \\
\hline Dulcitol & - & - & - & - & - & - & - & - \\
\hline Mannitol & - & - & - & - & - & - & A & A \\
\hline Sorbitol & - & - & - & - & - & - & A & A \\
\hline
\end{tabular}

${ }^{a}$ Symbols: A, positive result; $A_{3}$, positive result took at least 3 weeks to occur; slA, slightly positive result; -, no acid production.

as follows (translated from the German): "In morphological respects. . . shows a diversity and complication of structures. . .one might find long or short, straight or curved single rods. More often, however, one can see a variety of forms: Interlinked rods, more or less curved, result in the formation of wavy or winding threads of strongly twisted spirals. . an immense possibility of structural variation arises from the fact that the individual links within the groups may show unequal curvature. In this way we find very different curvatures and torsions - a pattern of scrolls and runes." In 1900 , Migula placed Weibel's organisms in the genus Spirosoma.
This genus was dropped from the 6 th edition of Bergey's Manual (2) because cultures of spirosomas were no longer available and because the descriptions of the species did not meet the taxonomic criteria of the day. The generic name Spirosoma was validly published and is legitimate (3).

From the above-mentioned descriptions by Weibel and Migula and from our observations of the morphology of the yellow-pigmented group of organisms (Fig. 1), there can be little doubt that $M$. flavus ATCC 23276, Spirosoma sp. strains 1 and 2 , and our strain 5 are organisms similar to those originally placed in the genus Spirosoma. We therefore concur with 


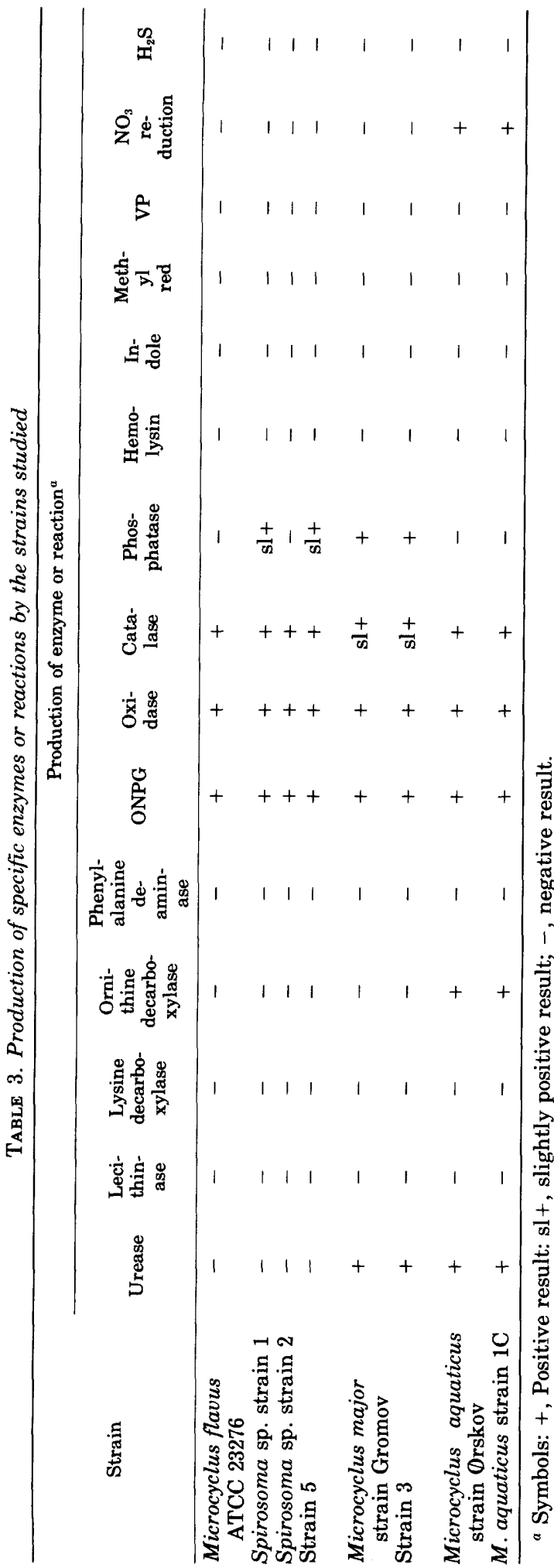

Claus et al. (5), who studied the first three named strains and suggested that these organisms be placed in the genus Spirosoma. An emended description of the genus follows:

Genus Spirosoma Migula 1900 emend.

(Spi.ro.soḿ a. Gr. n. spira a coil; Gr. n. soma body; M. L. neut. n. Spirosoma coiled body.)

Rods, 0.5 to 1.0 by 1.5 to $50.0 \mu \mathrm{m}$ with various degrees of curvature, often resulting in rings, coils, and undulating filaments. The outer diameters of the rings range from 1.5 to $3.0 \mu \mathrm{m}$. Nonmotile. Resting stages are not known. Gram-negative. Colonies contain a pale yellow, non-water-soluble pigment.

Metabolism is respiratory; acids are produced aerobically from a variety of carbohydrates. Strictly aerobic. Chemoorganotrophic.

The $\mathrm{G}+\mathrm{C}$ content of the DNA is 51.0 to 52.9 mol\% (thermal denaturation).

Isolated from soil and fresh water.

The types species (monotype) is $S$. linguale (Eisenberg) Migula 1894.

The four yellow-pigmented strains described above (M. flavus ATCC 23276, Spirosoma sp. strains 1 and 2, and our strain 5) conform to Eisenberg's (7) original description of $V$. linguale, and Migula's $(15,16)$ later descriptions of $S$. linguale, and they should be considered as strains of that species. Since the type strain of $M$. flavus Raj 1970 is placed in the species $S$. linguale (Eisenberg 1891) Migula 1894, the name $M$. flavus is a later subjective synonym of $S$. linguale. In the absence of the type strain of S. linguale, Spirosoma sp. DSM 74 is here designated as the neotype strain for the species. An emended description of this species follows.

Spirosoma linguale (Eisenberg 1891) Migula 1894 (Basonym: Vibrio linguale Eisenberg 1891; synonym Microcyclus flavus Raj 1970.)

(lin.guá le. L. adj. linguale of the tongue.)

Rods varying from short, nearly straight cells to longer, curved cells in which the degree of curvature varies giving rise to rings, coils, and serpentine, undulating filaments. The cell diameter varies from 0.5 to $1.0 \mu \mathrm{m}$, and the length of the cells varies from 1.5 to $50.0 \mu \mathrm{m}$. Rings and coils may be from 1.5 to $3.0 \mu \mathrm{m}$ in outer diameter. Gram-negative. The cells are nonmotile and nonflexible. Pigmentation on MS agar is from pale to medium yellow.

Metabolism is respiratory. No growth occurs under an anaerobic seal of pyrogallol- $\mathrm{KOH}$. Acid is produced oxidatively from many carbohydrates but not from alcohols. Oxidase and catalase are produced. Gelatin, starch, and tributyrin are hydrolyzed, but cellulose and chitin are not. Glycerol phosphate, succinate, tar- 
TABLE 4. Hydrolytic reactions of the strain studied

\begin{tabular}{|c|c|c|c|c|c|c|c|c|}
\hline \multirow[b]{2}{*}{ Strain } & \multicolumn{8}{|c|}{ Hydrolytic reactions $^{a}$} \\
\hline & $\begin{array}{l}\text { Cellu- } \\
\text { lose }^{b}\end{array}$ & $\begin{array}{l}\text { Chi- } \\
\text { tin }\end{array}$ & $\begin{array}{l}\text { Gela- } \\
\text { tin }\end{array}$ & Starch & Casein & $\begin{array}{l}\text { Es- } \\
\text { cu- } \\
\text { lin }\end{array}$ & $\begin{array}{l}\text { Tri- } \\
\text { bu- } \\
\text { tyrin }\end{array}$ & Litmus milk \\
\hline $\begin{array}{l}\text { Microcyclus flavus } \\
\text { ATCC } 23276\end{array}$ & - & - & + & $\mathrm{sl}+$ & $\mathrm{sl}+{ }_{3}$ & + & + & $\begin{array}{l}\text { Soft curd, reduction, } \\
\text { reoxidation }\end{array}$ \\
\hline Spriosoma sp. strain 1 & - & - & + & $\mathrm{sl}+$ & $\mathrm{sl}+{ }_{3}$ & + & + & $\begin{array}{l}\text { Soft curd, reduction, } \\
\text { reoxidation }\end{array}$ \\
\hline Spirosoma sp. strain 2 & - & - & + & sl+ & - & - & + & $\begin{array}{l}\text { Soft curd, reduction, } \\
\text { reoxidation }\end{array}$ \\
\hline Strain 5 & - & - & + & $\mathbf{s l}+$ & $\mathrm{sl}+{ }_{3}$ & + & + & Slightly alkaline \\
\hline $\begin{array}{l}\text { Microcyclus major } \\
\text { strain Gromov }\end{array}$ & - & - & $\mathbf{s l}+$ & Wide & - & + & + & No change \\
\hline Strain 3 & - & - & + & Wide & - & + & + & No change \\
\hline $\begin{array}{l}\text { Microcyclus aquaticus } \\
\text { strain Ørskov }\end{array}$ & - & - & - & - & - & - & + & Very alkaline \\
\hline$M$, aquaticus strain $1 \mathrm{C}$ & - & - & - & - & - & - & + & Very alkaline \\
\hline
\end{tabular}

a Symbols: + , positive result; $+_{3}$, positive result after at least 3 weeks; sl + , slightly positive; - , negative result.

${ }^{b}$ Substrate.

TABLE 5. Utilization of single carbon sources by the strains studied

\begin{tabular}{|c|c|c|c|c|c|c|c|c|c|c|c|}
\hline \multirow[b]{2}{*}{ Strain } & \multicolumn{11}{|c|}{ Utilization of carbon source ${ }^{a}$} \\
\hline & $\begin{array}{l}\text { Ace- } \\
\text { tate }\end{array}$ & $\begin{array}{l}\text { Ben- } \\
\text { zoate }\end{array}$ & $\begin{array}{l}\text { Cit- } \\
\text { rate }\end{array}$ & $\begin{array}{l}\text { For- } \\
\text { mate }\end{array}$ & $\begin{array}{l}\text { Glyc- } \\
\text { erol } \\
\text { phos- } \\
\text { phate }\end{array}$ & $\begin{array}{l}\text { Meth- } \\
\text { yla- } \\
\text { mine }\end{array}$ & $\begin{array}{l}\text { Pro- } \\
\text { pio- } \\
\text { nate }\end{array}$ & $\begin{array}{c}\text { Suc- } \\
\text { ci- } \\
\text { nate }\end{array}$ & $\begin{array}{l}\text { Tar- } \\
\text { trate }\end{array}$ & $\begin{array}{l}\text { Malo- } \\
\text { nate }\end{array}$ & $\begin{array}{l}\text { Meth- } \\
\text { anol }\end{array}$ \\
\hline $\begin{array}{l}\text { Microcyclus flavus } \\
\text { ATCC } 23276\end{array}$ & - & - & - & - & + & - & - & + & + & + & - \\
\hline $\begin{array}{l}\text { Spirosoma sp. } \\
\text { strain } 1\end{array}$ & - & - & - & - & + & - & - & + & + & + & - \\
\hline $\begin{array}{l}\text { Spirosoma sp. } \\
\text { strain } 2\end{array}$ & - & - & - & - & + & - & - & + & + & + & - \\
\hline Strain 5 & - & - & - & - & + & - & - & + & + & + & - \\
\hline $\begin{array}{l}\text { Microcyclus major } \\
\text { strain Gromov }\end{array}$ & - & - & - & - & - & - & - & + & - & - & - \\
\hline Strain 3 & - & - & - & - & - & - & - & + & - & - & - \\
\hline $\begin{array}{l}\text { Microcyclus aquati- } \\
\text { cus strain Orskov }\end{array}$ & + & - & + & + & - & - & - & + & - & + & + \\
\hline $\begin{array}{l}\text { M. aquaticus strain } \\
1 \mathrm{C}\end{array}$ & + & - & + & + & - & - & - & + & - & + & + \\
\hline
\end{tabular}

${ }^{a}$ Symbols: +, utilized; -, not utilized.

trate, and malonate may be used as sole sources of carbon, but acetate, benzoate, citrate, formate, methylamine, propionate, and methanol cannot. Urease, lecithinase, lysine decarboxylase, ornithine decarboxylase, and phenylalanine deaminase are not produced. Indole, acetylmethylcarbinol, and $\mathrm{H}_{2} \mathrm{~S}$ are not produced. Nitrate is not reduced. The $\mathrm{G}+\mathrm{C}$ content of the DNA ranges from 51.0 to $52.9 \mathrm{~mol} \%$ (thermal denaturation).

The neotype strain is DSM 74 (Spirosoma sp. strain 1). A description of this strain is given in Tables 1 through 7.
M. major strain Gromov and our strain 3 are nearly identical but differ significantly from both $M$. flavus ATCC 23276 and $M$. aquaticus strain Orskov. For the two former strains we suggest the establishment of a new genus, Flectobacillus, with the following description.

\section{Flectobacillus gen. nov.}

(Flec.to.ba.cil' lus. L. v. flecto to curve; L. n. bacillus a little staff, rod; M. L. mas. n. Flectobacillus curved rod.)

Straight to curved rods, the degree of curvature varying among individual cells within a 


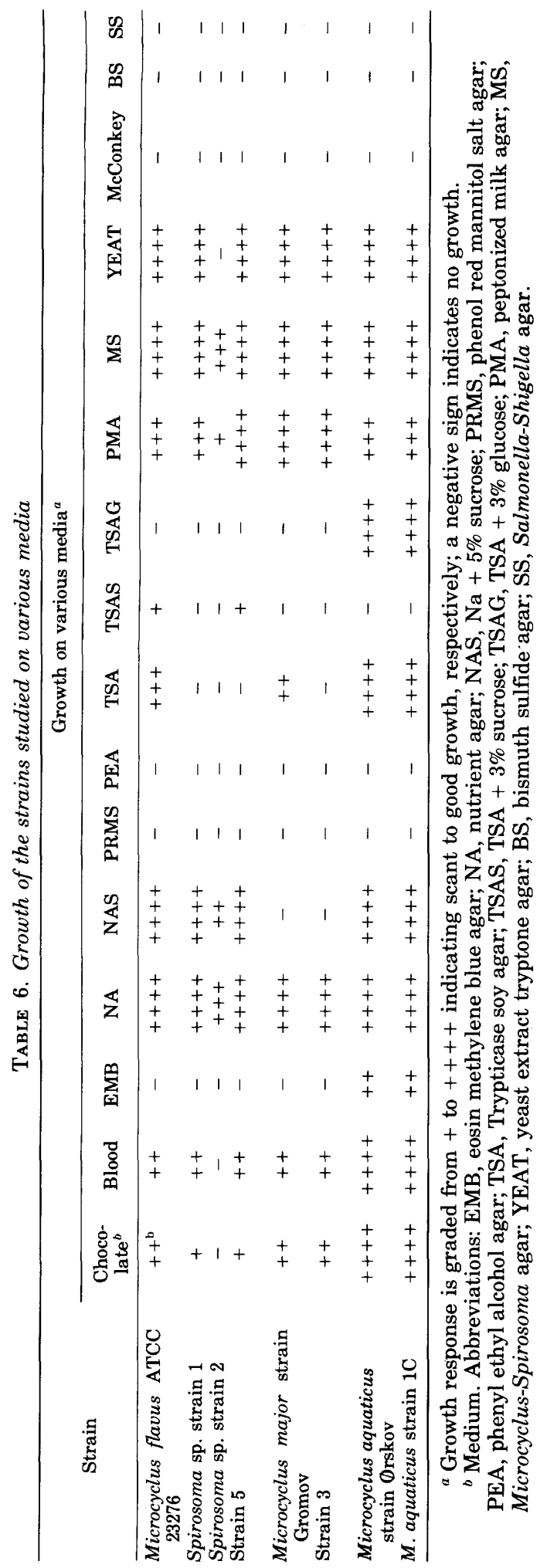

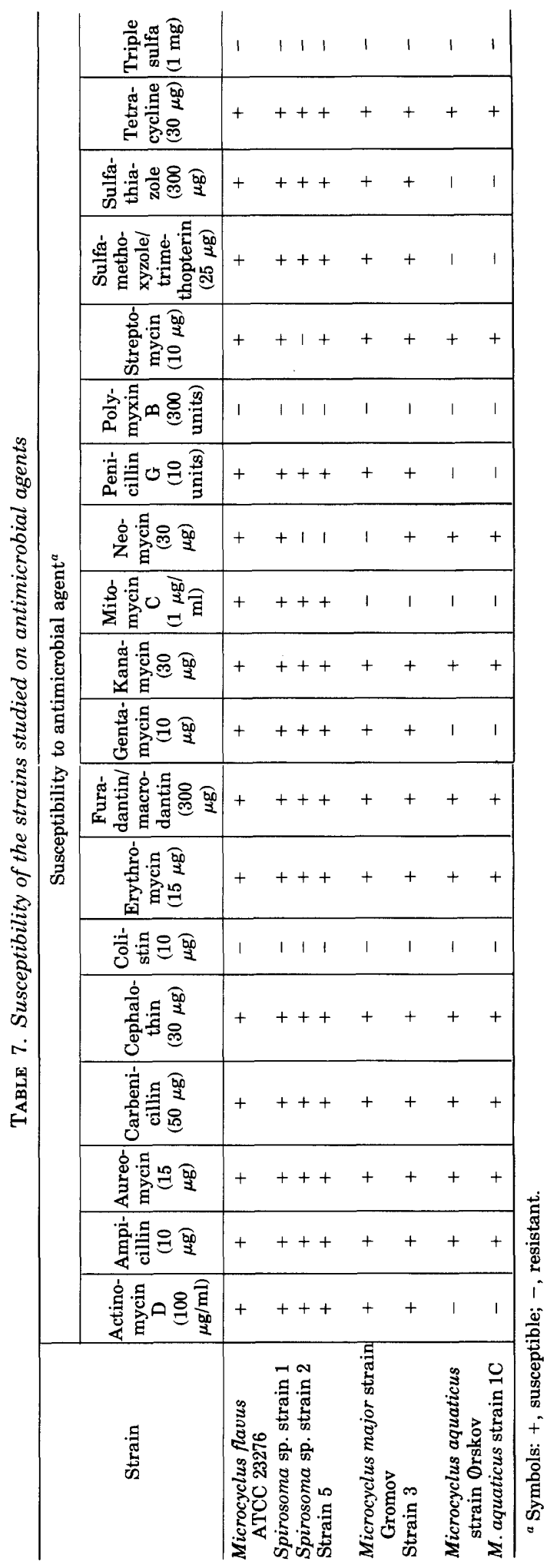



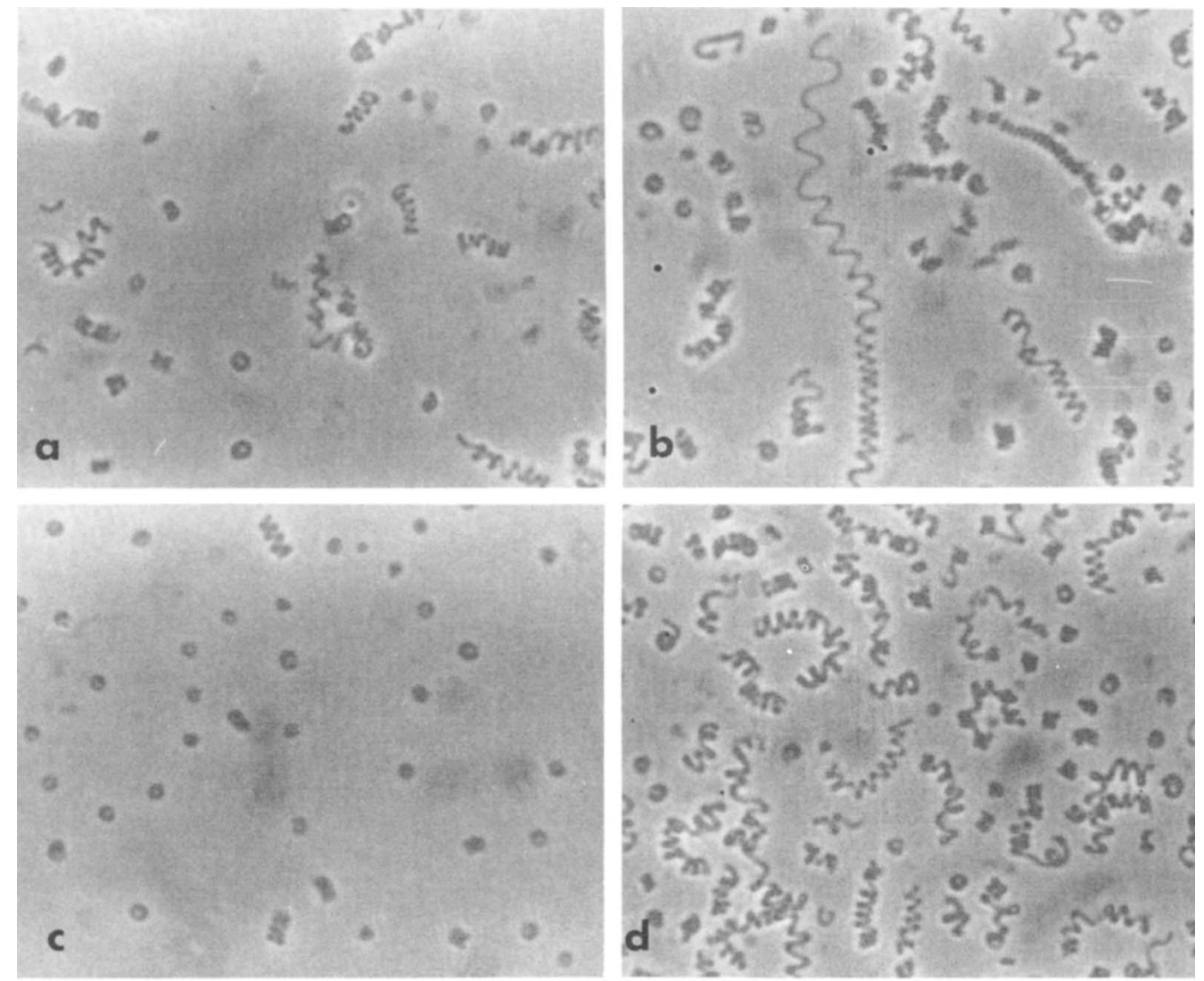

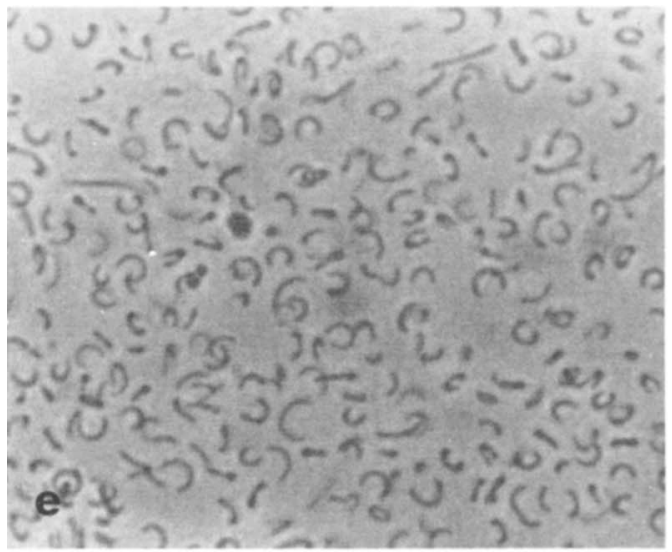

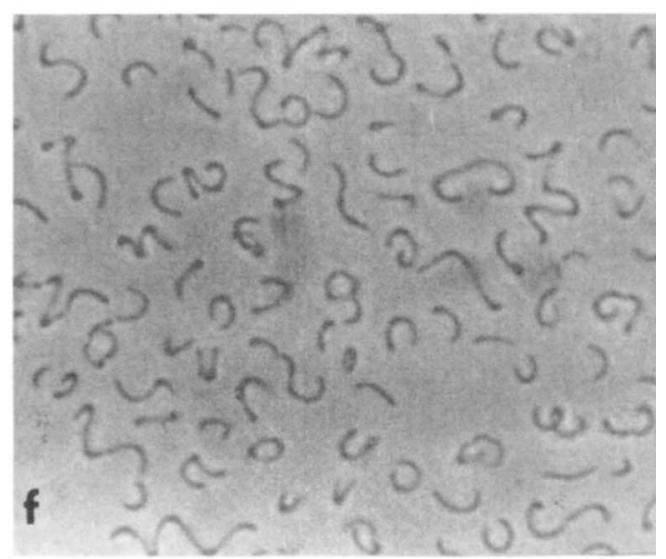

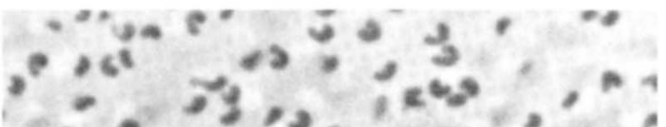

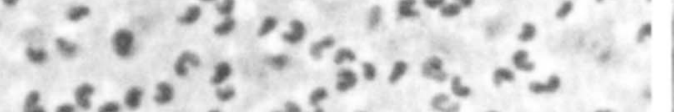

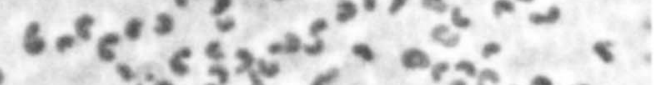
ialo

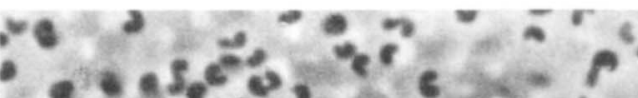
is.

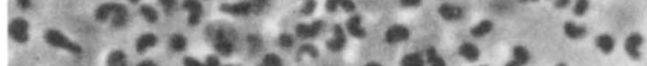

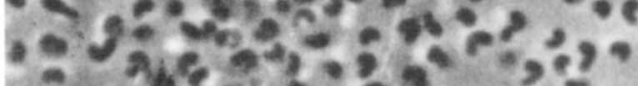

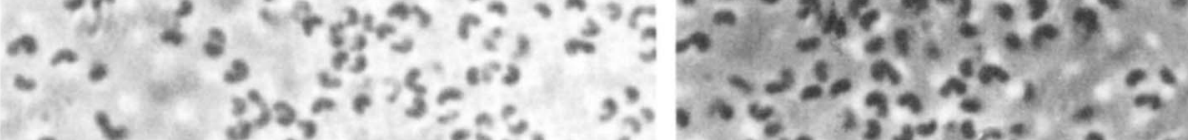

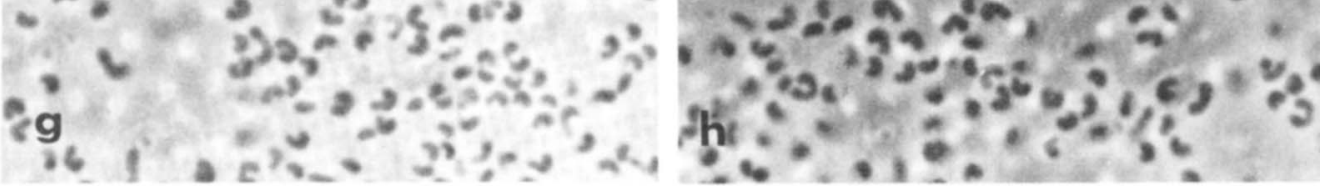


culture; the most abundantly occurring are cells in the shape of the letter $\mathrm{C}$. The cells measure 0.6 to 1.0 by 1.5 to $5.0 \mu \mathrm{m}$. Long sinuous filaments up to $50 \mu \mathrm{m}$ long are present. Rings 5 to $10 \mu \mathrm{m}$ in outer diameter are formed by overlapping of the ends of a cell. Coils or helical spirals are infrequently formed. Gramnegative. Nonmotile. Not flexible. Resting stages are not known. Colonies on MS agar contain a pale pink or rose-colored, non-watersoluble pigment.

Metabolism is respiratory; acids are produced aerobically from a variety of carbohydrates. Strictly aerobic. Chemoorganotrophic.

Isolated from fresh water.

The $\mathrm{G}+\mathrm{C}$ content of the DNA ranges from 39.5 to $40.3 \mathrm{~mol} \%$ (thermal denaturation).

The type species is $F$. major (Gromov) comb. nov.

Flectobacillus major (Gromov 1963) comb. nov. (Basonym: Microcyclus major Gromov 1963.)

(ma' jor. L. adj. major larger.)

Rods varying from nearly straight to crescent shaped, to long, sinuous filaments. Rings with an outer diameter of 5 to $10 \mu \mathrm{m}$ also occur. The cells vary in diameter from 0.6 to $1.0 \mu \mathrm{m}$, and the usual length is 1.5 to $5.0 \mu \mathrm{m}$. Coiled filaments are produced infrequently. Gram-negative. Nonmotile and nonflexible. Pigmentation on MS agar is a pale pink to rose color.

Metabolism is respiratory. No growth occurs under an anaerobic seal of pyrogallol-KOH. Acid is produced oxidatively from many carbohydrates but not from alcohols. Oxidase, catalase, and phosphatase are produced. Gelatin, starch, esculin, and tributyrin are hydrolyzed, but cellulose and chitin are not. Succinate, but not acetate, benzoate, citrate, formate, glycerol phosphate, methylamine, propionate, tartrate, malonate, or methanol, may be utilized as a sole source of carbon. Urease is produced, but lecithinase, lysine decarboxylase, ornithine decarboxylase, and phenylalanine deaminase are not. Indole, acetylmethylcarbinol, and $\mathrm{H}_{2} \mathrm{~S}$ are not produced. Nitrate is not reduced. The $\mathrm{G}+\mathrm{C}$ content of the DNA ranges from 39.5 to 40.3 mol\% (thermal denaturation).

The type strain of $F$. major is, by monotypy, strain Gromov (= BKM 859 = DSM 103). A description of this strain is given in Tables 1 through 7.

The removal of $M$. flavus and $M$. major from the genus Microcyclus necessitates that the definition of this genus be modified as follows.

Genus Microcyclus Orskov emend.

Curved rods which measure 0.5 to 1.0 by 1.0 to $3.0 \mu \mathrm{m}$. Rings with an outer diameter of 0.7 to $3.0 \mu \mathrm{m}$ are infrequently formed. Filaments and coils are not produced. Gram-negative. Nonmotile. Resting stages not known. Colonies on MS agar are nonpigmented to cream colored.

Metabolism is respiratory; acids are produced from several carbohydrates and alcohols. Strictly aerobic. Chemoorganotrophic.

Isolated from soil and fresh water.

The $\mathrm{G}+\mathrm{C}$ content of the DNA ranges from 66.3 to $68.4 \mathrm{~mol} \%$.

The type species is $M$. aquaticus. The type strain (by monotypy) of $M$. aquaticus is strain Orskov, a description of which is given in Tables 1 through 7 .

It seems premature to attempt to place the genera Microcyclus, Spirosoma, and Flectobacillus into families until their relationships with other genera are better known.

The lack of cultures of these organisms for a long time is somewhat surprising when it is considered that Weibel succeeded in isolating several strains, and Spirosoma was the first genus in the family Spirillaceae in Migula's "System der Bakterien" (16). Moreover, the unusual morphology of these organisms makes it relatively easy to recognize them. In the course of isolating some of the strains used in this study, we repeatedly saw similar morphological forms in bodies of water. These sites included fill ponds, the Tangipahoa and Trinity rivers in Louisiana and Texas, respectively, a canal in New Orleans, the Ponchatoula Creek, and runoff from rice fields. Two strains which are morphologically similar to $F$. major have been recently isolated by us and are currently being studied.

\section{ACKNOWLEDGMENT}

This work was supported by a grant from the Graduate Research Council of Louisiana State University.

\section{REPRINT REQUESTS}

Address reprint requests to: Dr. John M. Larkin, Department of Microbiology, Louisiana State University, Baton Rouge, LA 70803.

\section{LITERATURE CITED}

1. Altazan, D., J. M. Larkin, and M. D. Socolofsky. 1973. Some preliminary observations on Spirosoma. La. Acad. Sci. 38:58-60.

2. Bergey, D. H., R. S. Breed, and E. G. D. Murray. 1948.

Fig. 1. Phase micrographs of (a) M. flavus ATCC 23276, (b) Spirosoma sp. strain 1, (c) Spirosoma sp. strain 2, (d) strain 5, (e) $M$. major strain Gromov, (f) strain 3, (g) $M$. aquaticus strain $0 r s k o v$, and $(h) M$. aquaticus strain $1 \mathrm{C}$. All are magnified $\times 1,050$ except $(\mathrm{g})$ and $(\mathrm{h})$, which are $\times 2,640$. 
Bergey's manual of determinative bacteriology, 6th ed. The Williams and Wilkins Co., Baltimore.

3. Buchanan, R. E., J. G. Holt, and E. F. Lessel, Jr. 1966. Index Bergeyana. The Williams and Wilkins Co., Baltimore.

4. Claus, D. 1967. Taxonomy of some highly pleomorphic bacteria. Spisy Prirodoved. Fak. Univ. J. E. Purkyne Brne 40:254-257.

5. Claus, D., J. E. Bergendahl, and M. Mandel. 1968 DNA base composition of Microcyclus species and organisms of similar morphology. Arch. Mikrobiol. 63:26-28.

6. Dworkin, M. 1969. Sensitivity of gliding bacteria to actinomycin D. J. Bacteriol. 98:851-852.

7. Eisenberg, J. 1891. Bacteriologische Diagnostik, p. 212. Hilfstabellen zum Gebrauche beim Praktischen Arbeiten, vol. VII-XXX. 3 Aufl. Leopold Voss, Hamburg.

8. Gordon, R. E., and J. M. Mihm. 1957. A comparative study of some strains received as nocardiae. J. Bacteriol. 73:15-27.

9. Gromov, B. V. 1963. A new bacterium of the genus Microcyclus. Dokl. Akad. Nauk. SSSR 152:733-734.

10. Holding, A. J., and J. G. Collee. 1971. Routine biochemical tests, p. 1-33. In J. R. Norris and D. W. Ribbons (ed.), Methods in microbiology, vol. 6A. Academic Press Inc., New York.

11. Hugh, R., and E. Leifson. 1953. The taxonomic significance of fermentative versus oxidative metabolism of carbohydrates by various gram-negative bacteria. J. Bacteriol. 66:24-26.

12. Lapage, S. P., P. H. A. Sneath, E. F. Lessel, V. B. D.
Skerman, H. P. R. Seeliger, and W. A. Clark (ed.). 1975. International code of nomenclature of bacteria, 1976 revision. American Society for Microbiology, Washington, D. C.

13. Mandel, M., and J. Marmur. 1968. Use of ultraviolet absorbance temperature for determining the guanine plus cytosine content of DNA, p. 195-206. In S. P. Colowick and N. W. Kaplan (ed.), Methods in enzymology, vol. 12B. Academic Press Inc. New York

14. Marmur, J. 1961. A procedure for the isolation of deoxyribonucleic acid from microorganisms. J. Mol. Biol. $3: 208-218$.

15. Migula, W. 1894. Über ein neues System der Bakterien. Arb. Bakteriol. Inst. Karlsruhe. 1:235-238.

16. Migula, W. 1900. System der Bakterien. Vol. 2, Publishing House of Gustav Fisher, Jena.

17. Orskov, J. 1923. Beschreibung eines neuen Microben, Microcyclus aquaticus, mit eigentümlicher Morphologie. Zentrabl. Bakteriol. Parasitenkd. Infektionskr. Hyg. Abt. I Orig. 107:180-184.

18. Raj, H. D. 1970. A new species-Microcyclus flavus. Int. J. Syst. Bacteriol. 20:61-81.

19. Staley, J. T. 1974. Genus Microcyclus, p. 214. In R. E. Buchanan and N. E. Gibbons (ed.), Bergey's manual of determinative bacteriology, 8th ed. The Williams and Wilkins Co., Baltimore.

20. Weibel, E. 1887. Untersuchungen über Vibrionen. Zentralbl. Bakteriol. Parasitenkd. Infektionskr Hyg. Abt. 1 Orig. 4:225-232.

21. Weibel, E. 1888. Untersuchungen über Vibrionen. Zentralbl. Bakteriol. Parasitenkd. Infektionskr. Hyg. Abt. 1 Orig. 4:224-232. 